\section{Sir Maurice Craig}

Psychiatry has suffered a grievous loss by the death on January 6 of Sir Maurice Craig, consulting physician in psychological medicine to Guy's Hospital, and consulting neurologist to the Ministry of Pensions. Born in 1866, he received his education at Bedford Grammar School and Caius College, Cambridge. $\mathrm{He}$ was early interested in mental disorders, and was one of the many distinguished men who have gained the Gaskell Gold Medal of the Royal Medico-Psychological Association.

For more than fifteen years, Craig was a resident physician at Bethlem Royal Hospital, years in which he gained a very wide experience in psychiatry, and in the teaching of the subject to students. From 1907 Craig confined himself to consulting work, and built up a very extensive practice. He delivered the Bradshaw Lecture at the Royal College of Physicians on "Mental Symptoms in Physical Disease" in 1922, and the Maudsley Lecture on "Some Aspects of Education and Training in Relation to Mental Disorder" in the same year. In addition to numerous articles in medical journals, Craig published a book on "Nerve Exhaustion" which was much discussed on its appearance. In 1905 the first edition of his wellknown textbook on psychological medicine appeared; after exhausting three editions, the book was revised and rewritten in co-operation with Dr. Thomas Beaton and republished as the fourth edition in 1926.

During the War, Craig was a valued adviser on the care and treatment of nervous and mental disorders among officers and soldiers, and afterwards became consulting neurologist to the Ministry of Pensions, and a member of the War Office Committee on shell shock. He received the C.B.E. in 1919, and the honour of knighthood in 1921.

Sir Maurice Craig developed a profound interest in the early evidences of mental disease, and throughout his teaching life insisted on the importance of early symptoms. During the years of his consulting work, he became increasingly concerned in what are known as the psychoneuroses and neuroses. He was an enthusiastic and hard-working chairman of the medical committee of the Cassel Hospital at Penshurst, and chairman of the National Council for Mental Hygiene up to the time of his death.

Sir Maurice Craig enjoyed a very wide esteem and popularity among his professional brethren. He was made a governor of the Royal Hospitals of Bethlem and Bridewell; he became the president of the Section of Psychiatry, Royal Society of Medicine, and president of the Section for Mental Diseases at the centenary meeting of the British Medical Associa. tion in 1932. He was a vice-president of the International Committee for Mental Hygiene. His many appointments reflect his scientific interests, and his universal popularity.

It is impossible to write of Sir Maurice Craig without remembering his charm of manner, his delightful presence and popularity. $\mathrm{He}$ was ever ready to help and encourage a younger colleague, and was tireless in his devotion to his patients. Yet he could be quite fearless and outspoken in debate or criticism. His contribution to psychiatry may be summarised by his constant insistence on the importance of early symptoms in every form of mental disease, and the urgent need of early treatment; by his leadership in making psychiatry a part of general medicine, and freeing it as far as possible from legal restrictions; by the stimulus he has given to improving the education of medical students, practitioners and the general public in matters of mental health and hygiene. Lastly, Craig has focused a keen scientific inquiry on the place taken by fatigue in the etiology of mental disease. His death will be deplored by a very wide circle of scientific men.

\section{The Rev. S. A. McDowall}

The death on January 13 of the Rev. S. A. McDowall, chaplain and senior science master at Winchester College, will be felt as a deep personal loss by many Wykehamists and a wide circle of friends.

Stewart McDowall went up to Trinity College, Cambridge, from St. Paul's School and obtained first classes in both parts of the Natural Sciences Tripos. He became a demonstrator in the Biological Labora. tory and assistant superintendent of the Museum of Zoology at Cambridge. In 1905 he joined the staff of the Christian College at Madras as temporary professor of zoology, and a year later was appointed an assistant master at Winchester College. In 1908 he was ordained, and in 1915 became one of the College chaplains. In the same year he published the first of a number of works on science, philosophy and religion. "Evolution and the Spiritual Life" was the first expression of his beliefs that evolution was the method by which God had chosen progressively to create free beings, and that science had great gifts to bring to the service of the Christian world.

McDowall was a select preacher at Oxford 1916, at Cambridge 1920, and Hulsean lecturer 1923-24. "Evolution and the Doctrine of the Trinity" appeared in 1919, and the Hulsean Lectures were published as "Evolution, Knowledge and Revelation". Meanwhile, he had been appointed senior science master at Winchester College in 1918, and since that time had much to do with the development of the science teaching both of science specialists and of a general science course which is taken by the whole of the upper part of the school.

McDowall held vigorously the view that every citizen should have sufficient training to appreciate the scientific problems which only the highly specialised technician can be expected to solve, and that all should have some acquaintance with the history of man's growing control over his environment, particularly as it has been attained by scientific methods. During the last year of a boy's school life, he aimed at introducing to him the facts and theories of modern biology in their bearing on the life of a civilised community. His views on this subject were incorporated in his last book, "Biology and Mankind", published in 1931.

For many years MoDowall was curator of the College museum and president of the Natural History Society, of which the biennial reports show the 
wide range of interests which he inspired in his young friends. To his psychological knowledge and insight, and to his sympathy with differing minds, Dr. William Brown has borne eloquent witness in The Times. He was a man of great personal charm and a brilliant conversationalist. His intellectual and æsthetic interests were very wide and led him to seek new experiences and to encourage others to share them. Successive generations of Wykehamists testify to the way in which he stimulated the development of their minds by his own enthusiasm for life.

\section{Mr. Kenneth F. Armstrong}

ThE death of Kenneth Armstrong on January 3, at twenty-five years of age, while on a visit to the Austrian Tyrol with another young and promising Oxford graduate, John Howard, who was an old schoolfellow, is a grievous tragedy. While ski-ing, they encountered an avalanche which seems to have swept Howard to his death, and it appears that Armstrong, in his endeavour to recover his com panion, fell into a ravine, being killed as the result of crashing on a rock.

Armstrong was the son of Dr. E. F. Armstrong and the grandson of Prof. H. E. Armstrong. His death is a personal shock to everyone who knew him, and it is regrettable that chemistry should be deprived of the contribution to its progress so clearly destined to come from his labours. There can be no doubt that, had he lived, he would have done full credit to his scientific ancestry.

Armstrong received his early education at Oundle School, whence he went to Magdalen College, Oxford, in 1927, having been awarded a demyship there. $\mathrm{He}$ gained a first class in the Honour School of Chemistry at Oxford in 1931. After graduating, he was awarded a Julia Henry scholarship and proceeded to Harvard University and commenced work on chlorophyll problems with Prof. J. B. Conant. In the two years spent there, he made a valuable advance in this difficult field, and part of the work has been published in the Journal of the American Chemical Society. Armstrong's extensive knowledge of this subject enabled him to contribute a lucid article on presentdayknowledge ofchlorophyll to Chemistry and Industry.

Soon after his return to Oxford in 1933, Armstrong was eleeted to a Harmsworth senior scholarship at Merton College and was quickly at work on several problems of his own choice. Among these were : the nature of the colouring matter of the red moth; the identity of the glucoside in the Japanese laurel (Aucubine); and the configuration of the cyclic polyalcohols, particularly quebrachol. Recently, in collaboration with Prof. R. Robinson, some work on the oxidation effects of selenium dioxide was published. Armstrong recently collaborated with his father in producing a new edition of the well-known books on the simple carbohydrates and the glycosides.

His friends will ever remember with respect and admiration Armstrong's unfailing kindliness on all occasions. His lamented death deprives the Oxford school of organic chemistry of one of the most notable of the younger generation of research students.

\section{Dr. Eleanor Hull}

WE regret to record the death of Miss Eleanor Henrietta Hull, folklorist and Erse scholar, which took place at the age of seventy-five years, on January 14 , at Wimbledon.

Miss Hull was the daughter of Prof. Edward Hull, and was educated at Alexandra College and the Royal College of Science, Dublin. She studied Celtic and allied subjects under Pedersen, Kuno Meyer and R. Flower. An enthusiast for the study of Irish history and letters, she added sound scholarship to the movement for the revival of Erse and the rekindling of pride in Irish tradition. Apart from her own literary work, this took practical form in the foundation in 1899, with the assistance of Prof. York Powell, of the Irish Texts Society. As honorary secretary of the Society she enlisted the services of the foremost Erse scholars of the day, and was largely responsible for the publication of a number of valuable and important early Irish manuscripts. Miss Hull was at one time secretary of the Royal Asiatic Society. She had served as president of the Irish Literary Society of London and was a member of the Council of the Folklore Society.

Among her contributions to Irish studies her work on the Cuchulain Saga (1898) will always hold first place; but as a folklorist her "Folklore of the British Isles" (1928), in bringing some sort of system and order to the treatment of a mass of somewhat chaotic material, runs it close. Among other works worthy of note were her "Pagan Ireland and Early Christian Ireland" (1904), "A Text-Book of Irish Literature" (1906-7), "Cuchulain, the Hound of Ulster" (1909), and a "History of Ireland and Her People" (1926, 1931) in two volumes.

WE regret to announce the death of Arthur Lionel Pedder, on December 15, at the age of sixty-six years. He was mathematical tutor at Magdalen College, Oxford, from 1891 until 1925. He went to the College as a demy in 1886, and was elected fellow in 1894. Pedder was a very good teacher and was remembered with gratitude and affection by his pupils. He was one of the old-fashioned people who valued the educational training given by the curriculum and examinations of the old mathematical school as one of the best preparations for after-life; and was quite out of sympathy with the new system which, in his opinion, was of little or no use, except for those who intended to be professional mathematicians.

WE regret to announce the following deaths :

Mr. F. J. Blight, fellow of the Royal Society of Edinburgh and formerly chairman and managing director of Messrs. Charles Griffin and Co., Ltd., publishers of many scientific and technical works, on January 27, aged seventy-six years.

Dr. Michael Grabham, author of numerous books and papers on the natural history of Madeira, where he had lived for some seventy years, on January 28 , aged ninety-five years. 